\title{
A construct of code effectiveness: empirical findings and measurement properties
}

\section{Author:}

Mornay Roberts-Lombard' Mercy Mpinganjira ${ }^{1}$

Greg Wood ${ }^{2}$

Göran Svensson ${ }^{3}$

Affiliation:

${ }^{1}$ University of

Johannesburg,

South Africa

${ }^{2}$ Deakin University,

Australia

${ }^{3}$ Kristiania University

College, Norway

\section{Correspondence to:}

Prof. M. Roberts-Lombard, Department of Marketing Management,

University of

Johannesburg, C-Ring 6,

Kingsway Campus,

Auckland Park, 2006

South Africa

Tel. no.:

+27115593031

E-mail:

mornayrl@uj.ac.za

DOI:

10.15249/10-1-95

\section{Keywords:}

business ethics; corporate governance; business policy; South Africa

\section{Abstract}

The purpose of the study is to examine and describe the use of codes of ethics in companies operating in South Africa. The population included the company secretaries of the top 500 companies operating in the South African corporate sector. The findings stipulate that South African companies need to understand that their employees are diverse in beliefs and opinions and as a result do not all have similar ethical value systems. Therefore, ethical education is imperative to ensure a stronger focus on the offering of ethics programmes aligned with the business philosophy of the company.

\section{Introduction}

Over the past two decades, South African business has experienced significant modifications in ethical outlook. The country is unique, considering that it experienced a fundamental change due to the termination of apartheid and the establishment of its first democratically voted government in 1994. The country has also seen an intense transformation to the corporate management approach that guides proper business conduct (Price \& Van der Walt, 2013:430). This study therefore examines and describes the use of codes of ethics in 222 companies that have a code of ethics and operate within the borders of South Africa. Three dimensions that are influenced by the company code of ethics were tested, namely altruistic, mercenary and regulatory motives for action. Five statements in the questionnaire were used to measure 'altruistic', seven statements to measure 'mercenary', and four to measure 'regulatory'. A code of ethics (also known as a Code of Ethics Construct) refers to "a written set of guidelines issued by an organisation to its workers and management to help them 
conduct their actions in accordance with its primary values and ethical standards' (Business ethics dictionary, 2016).

Van Zyl and Lazenby (2012:65) and Somers (2001:186) argue that a code of ethics should highlight to a company's stakeholders and the business world that its commitment to an ethical corporate culture is strong. Kaptein (2008:982) argues that it should be noted that the focused interest of each stakeholder group is different and that the ethical accountability that companies have towards each stakeholder group also differs. For example, the key accountability that a company has to its investors is to secure a positive return on investments. On the other hand, the primary responsibility towards customers is to provide them with products and services of a high quality, and to employees it is to secure a healthy working environment. Considering this, a few cases of unethical business practices in South Africa are highlighted below.

The MTN Group, one of South Africa's largest corporate brands, is facing a $\$ 4.2$ billion lawsuit by Turkish cell phone company Turkcell based on accusations of corruption. Such business indignities have brought about an increased interest in South Africa in the field of business ethics (Loyd, Mey \& Ramalingum, 2014:569). The company was also fined $\$ 5.2$ billion in 2015 by the Nigerian telecommunications regulator for its failure to disconnect five million unregistered SIM cards (Fin24tech, 2015). Clover South Africa, South African Airways (SAA), Allied Bank of South Africa (ABSA), Fidentia Asset Management, Leisurenet, Tiger Brands, Premier Foods, Foodcorp, and Pioneer foods are companies that have been found guilty of unethical business practices in the last decade. These business practices were characterised by "claims of milk and bread price fixing, insider trading, bribery and fraud. Although ABSA, SAA, Foodcorp, Pioneer Foods, Tiger Brands and Clover SA survived and rebuilt their reputations; the other organisations were not so lucky" (Ukwanada, 2015). Although it is assumed that unethical behaviour is the outcome of bad practice by a few employees in a company, there is increased confirmation that corporate culture plays a central role in the support of ethical behaviour (Zona, Minoja \& Coda, 2013:267). Constantinescu and Kaptein (2015:337) emphasise that there should be more balance in the relationship between company culture and employee behaviour. They argue that there is a growing two-way relationship between company culture and employee behaviour within the business ethics realm, with one party supporting the other by stimulating and facilitating (un)ethical employee and company behaviour.

Considering the above discussion, it is apparent that a code of ethics in itself is not enough to guarantee that the employees of a company will actually exhibit ethical behaviour (Sims, 1992:507). Nor can it ensure that parties external to the company will be confident that the motives behind its development were purely altruistic and that the mercenary factor of business survival was not foremost in the minds of senior executives when they constructed and enacted the code. Globally, there is still much scepticism amongst the public regarding companies' motives for business ethics, because over the last forty years we have witnessed the same errant behaviours reappearing in a slightly different guise in different decades (Bisschoff \& Fullerton, 2011:17; Wood, 2002:62). We regularly see such things as baby milk formula debacles, oil spills in pristine oceans, car safety issues ignored at the expense of the motoring public, the collapse of financial institutions and 
rogue stock market traders surfacing, to the detriment of those who encounter these sharp practices and who suffer because of them (Wood, 2002:63). Whilst having a code is important, embracing its ethos and inculcating that ethos in the organisational culture are imperative. Therefore, a code of ethics must become a document that promulgates ethical behaviour (Van Zyl \& Lazenby, 2012:65). Kaptein (2011:236) agrees, stating that the success of a code of ethics depends on the ability of all stakeholders in the company (i.e. the board of directors, company management and employees) to understand its meaning and relevance to business practices. In addition, all employees should be empowered to practically apply such a code to daily business activities.

\section{Literature discussion}

This article builds on the work of Svensson, Wood and Callaghan (2004a; 2004b); Svensson, Wood and Callaghan (2006); and Svensson and Wood (2008), which examined reasons stated by companies as to why they believed that having a code of ethics had a positive effect upon their company. The previous work in this area suggested that the responses would fall into three categories, as illustrated in Figure 1:

Altruistic: A benefit was in evidence for the good of society, its stakeholders and employees that was not judged on the basis of a financial gain or a financial loss for the company.

Mercenary: A direct financial benefit to the company was believed to be in evidence.

Regulatory: A benefit was in evidence through the avoidance of behaviour that could lead to issues for the company, up to and including monetary fines from legal authorities.

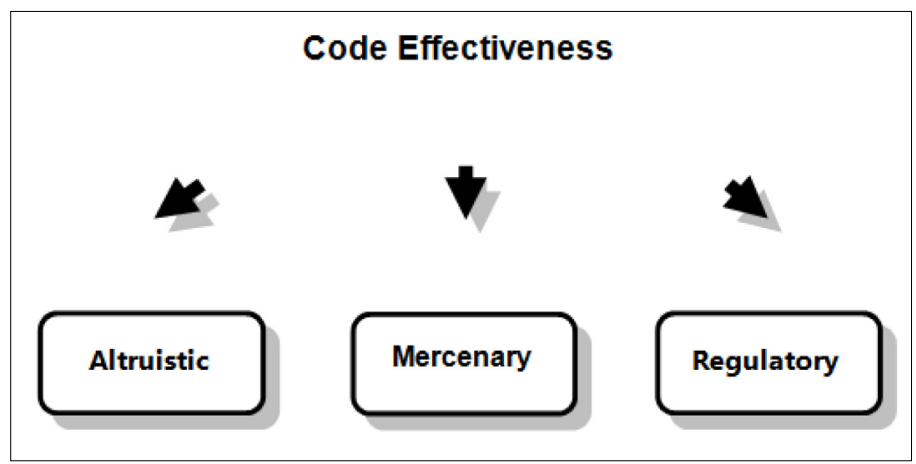

Figure 1: Code Effectiveness-construct: Properties of measurement model (Source: Researchers' own construct)

Each of the three categories is now briefly discussed.

\section{Altruistic ideals in the development of a code of ethics}

At the opening of the South African Parliament on 17 February 1995, Nelson Mandela stated, "We are conscious of the reality that corruption in many forms has deeply infected the fibre of our society. Precisely because we face the challenge of dealing 
with systematic corruption, we need a dispassionate and systematic approach to this question." And in 1994 the Institute of Directors in Southern Africa (IODSA) suggested that "there should be new guidelines for ethical practice in business enterprises in South Africa" (IODSA, 1994). Commenting on the situation in the early 1990s, Bisschoff and Fullerton (2011:14-15) argue that, at the time, there seemed to be a cultural mindset in South Africa that ethics might succumb to questionable actions, as organisations might choose to secure their long-term survival at the expense of being ethical and of obeying the law. This conundrum has been faced by societies all over the world ever since the inception of the capitalist system, which often sets self-interest at odds with the interests of society.

The importance of corporate governance in South Africa was highlighted by the publication of the King Report on Corporate Governance in November 1994 (IODSA, 2002). The focus of the report, widely referred to as King I, was to emphasise that it is essential for companies to be accountable to the societies in which they operate (Dekker, 2002). The King II Report (which appeared in 2002) clearly suggested that companies should become more transparent and fair in their business practices and take more responsibility for their actions, calling for companies to "become more active in their annual reporting on the nature and extent of [their] social, transformation, ethical, safety and health practices, the different environmental management policies and practices [they apply], as well as reporting on [their] stakeholders” Loyd et al. (2014:572).

Unethical business practices are also prevalent in the global business environment, with ethical scandals constantly making headlines. Ethical failures result in various costs and consequences for companies, such as financial losses, fines, executives losing their positions, eroded reputations and, in extreme cases, company closure. The Enron and Arthur Anderson cases are two high-profile cases that remain fresh in the mind more than ten years on (Schoeman, 2012:25). South African companies can develop an ethical framework for business practice by ensuring that company stakeholders have a strong belief in the manner in which the company conducts its business. This implies that business practice must be perceived as being mutually beneficial to all parties involved and not only profiting one of the parties in the relationship (Rossouw, 2012:5-6).

Wood (2002:63) states that ethical behaviour should be

[...] pursued for the altruistic desire to be ethical, not for the mercenary desire to profit from this latest strategic initiative. For if profit drives the motives, then one has missed the inherent truth in being ethical. That is, one does an action because it is the right thing to do, and not that if one appears to be ethical, then that action will be the "right" thing for the business.

The business practice of the company must therefore be guided by its business philosophy, which should clearly reflect ethical values, both internal and external to the organisation's operations. Ethical values are developed and managed from within the company to develop and strengthen external business relationships. 
All companies are in the corporate marketplace to make a profit. Profit should be the natural outcome of a company's business endeavours (Lea, 1999:152). In capitalist societies, companies come into existence and are permitted to flourish because it is believed that these companies have a critical role in enhancing the betterment of society (Goldman, Bounds, Buła \& Fudalinski, 2012:77). Business Unity South Africa (BUSA) (2009) emphasises that South African companies have a responsibility towards society to be responsible commercial citizens. This echoes the King III Report, which states that "responsible corporate citizenship is necessary to protect the sustainability of the company and to ensure the ability of future generations to meet their needs. The interests of shareholders and stakeholders coincide over the long term" (IODSA, 2009:22). Therefore, South African companies should uphold ethical business practices, with an emphasis on taking responsibility for their decisions and actions. This can be achieved, among other things, through sound management strategies and operations and ensuring that all necessary legal and regulatory safeguards are in place, as well as supporting organisational practices that are economically, socially and environmentally sustainable.

Maclagan (1992:322) stated in the early nineties that the pressure to perform is strong in many companies, often to the extent where it overrides personal ethical standards. Management may want to reconsider company pressures such as management by objectives, surpassing the previous year's accomplishments, cost-savings plans, and pay-to-performance schemes (Cant \& Van Niekerk, 2013:2-3), as these may be counterproductive to fostering ethical behaviour. In South Africa, as an emerging market economy, the concern is ever present that employees may be pressurised into engaging in unethical activities, and more so, that such behaviour may sadly be rewarded by the company, either overtly or covertly. Mirzayev (2015) supports this statement, asserting that "the corruption level in countries with developing emerging market economies is much higher than it is in developed countries". The business code of ethics should be one way of guiding the employees of companies to take the right course of action, one that considers simultaneously the potential benefits and downsides of their actions to a variety of stakeholders. Companies should not be lambasted for generating profits, but they need to examine the ways in which they achieve those profits and be cognisant of the value they place to much emphasis on the profit motive as maximiser of corporate effort (Loyd et al., 2014:571-572).

\section{Regulatory ideals in the development of a code of ethics}

The regulatory ideals of South African companies should be enforced to avoid litigation and fines and empower employees to be ethical in their daily operations, thereby preventing them from doing damage to the company. The King I Report (1994) thus focused not only on the fiscal and regulatory aspects of corporate governance In South Africa. By considering "a participative corporate governance system of enterprise with integrity, the King Committee in 1994 successfully formalised the need for companies to acknowledge that they no longer operate autonomously from the societies and the 
environments in which they function" (IODSA, 2009). The King III Report (2009) took a similar approach, but shifted from a 'comply or explain' paradigm to an 'apply or explain' one. This approach empowers company directors to decide that a proposed practice as stipulated in the King III Report is not necessarily to the benefit of the company and consider a different practice, provided that they are able to motivate their position (PWC, 2016).

The South African Business Ethics Survey 2013 established that there had been an increase in awareness of ethical standards and ethics management processes in companies since the late 2000s (Groenewald \& Geerts, 2013:12). This is an important development to note, as the ethical culture of a company is the communal set of beliefs about what the correct behaviour is and how ethical issues will be managed. This corporate culture provides a foundation for decision making at all levels in the company in all circumstances (Van Zyl \& Lazenby, 2012:62). Corporate culture in South Africa should therefore support the disclosure of practices in the organisation that are unethical or damaging towards internal or external stakeholders (Loyd et al., 2014:573). Whistle-blowers in South Africa are protected against occupational detriment by the Protected Disclosure Act of 2000. Despite this protection, government and private sector employees are of the opinion that "the example set by associates of the party-political elite and/or their family members and affiliates, and the absence of steps taken to prosecute them, set a poor example and limit the willingness of people to speak up" (Irwin, 2011:15).

The King III Report on corporate ethics has driven increased awareness of ethics in corporate South Africa (SAICA, 2014). The report places significant emphasis on company leadership as moral corporate citizens with sound ethical values. Boards are also advised to become more aware of legitimate stakeholder interests when decisions are made. Key stakeholders are identified and direction is provided about how to manage these relationships and the level of disclosure required. In addition, the report highlights the importance of compliance with applicable laws, regulations, non-binding rules and standards. Companies are advised to have an appropriately independent compliance function to advise the board on such matters (Seegers, 2009:8).

Although the Companies Act requires social and ethics committees to report on the ethical performance to shareholders at the company's annual general meeting, reporting on ethical performance in the integrated annual report is a recommendation of King III (Schoeman, 2012:25). The report on ethical performance should include all responsibilities and practices of the social and ethics committee as well as the measurement of the company's ethics, both of which should be presented in relation to the company's business strategy and goals. Furthermore, Schoeman concludes that an added benefit of regular assessment of a company's ethics derives from the dictum that 'you can't manage what you don't measure'. While this is a slight overstatement, ethics can surely be better and more easily managed if it is measured. It is a fact that the governance of companies is influenced by external regulations. It would be naïve to suggest that compliance with regulatory elements in the business environment is not going to be a focus area in any code in terms of its perceived worth to the company (Loyd et al., 2014:572). 


\section{Methodology}

The construct of a code effectiveness study was quantitative and exploratory in nature and was conducted during 2014. The population of interest for the study consisted of the top 500 South African companies. The list of companies was obtained from the TopCo 2014 publication, which listed these companies based solely on their financial performance. A census was conducted, with responses received from 222 companies. The research method applied to the study was a questionnaire survey, conducted by means of the Computer Assisted Telephone Survey (CATI) method. The head of ethics or company secretary of each company was asked to answer up to fifteen statements relating to the effect of a code of ethics on their business practices.

Individual respondents at each company were contacted by telephone prior to the interview to determine their suitability to respond to the questionnaire. Each respondent was briefly orientated about the study to arouse their interest and stimulate a willingness to partake in the survey.

\section{Measures}

Participants responded to a five-point Likert-type scale anchored at 'Strongly agree' (5), and 'Strongly Disagree'(1). The indicators were adopted from Svensson et al. (2006) and are provided in Table 1.

Table 1: Questionnaire items

\begin{tabular}{|c|c|}
\hline Construct & Statement: Our Code has a positive effect on ... \\
\hline Altruistic & $\begin{array}{l}\text {... earning respect of stakeholders. } \\
\ldots \text { that is integral to company philosophy. } \\
\ldots \text { being a good corporate citizen. } \\
\ldots \text { enhancing staff morale. } \\
\ldots \text { increasing staff confidence. }\end{array}$ \\
\hline Mercenary & $\begin{array}{l}\text {... improving business performance. } \\
\text {... enhancing company reputation. } \\
\text {... increasing long-term interests. } \\
\text {... assisting profit. } \\
\text {... improving competitive differentiation. } \\
\text {... increasing customer loyalty. }\end{array}$ \\
\hline Regulatory & $\begin{array}{l}\text {... avoiding potential problems. } \\
\text {... focusing on employee efforts. } \\
\text {... avoiding litigation (i.e. lawsuits). } \\
\text {... avoiding fines. }\end{array}$ \\
\hline
\end{tabular}




\section{Empirical findings}

The sample corporate characteristics of this study are summarised in Table 2. The 'nature of business' cuts across South African industries and business sectors. The companies in the sample range from medium-sized to large or very large, based on annual turnover and number of employees. Overall, the sample represents a broad spectrum of the South African corporate environment.

Table 2: Sample characteristics: nature of business, turnover and number of employees

\begin{tabular}{|c|c|c|c|c|c|c|}
\hline $\begin{array}{l}\text { Nature of } \\
\text { business }\end{array}$ & Count & $\begin{array}{c}\text { Sector } \\
\text { distribution } \\
(\%)\end{array}$ & Turnover (in USD) & Count & $\begin{array}{l}\text { Number of } \\
\text { employees }\end{array}$ & Count \\
\hline $\begin{array}{l}\text { Accounting, café or } \\
\text { restaurant }\end{array}$ & 4 & 1.8 & $\leq 5$ million & 25 & $\leq 200$ & 9 \\
\hline $\begin{array}{l}\text { Agriculture, forestry } \\
\text { or fishing }\end{array}$ & 4 & 1.8 & 5 million $-<25$ million & 40 & $201-500$ & 46 \\
\hline $\begin{array}{l}\text { Communication } \\
\text { services }\end{array}$ & 14 & 6.3 & 25 million $-<100$ million & 45 & $501-1000$ & 33 \\
\hline Construction & 8 & 3.6 & 100 million $-<1000$ million & 26 & $1001-5000$ & 65 \\
\hline $\begin{array}{l}\text { Cultural or recreational } \\
\text { services }\end{array}$ & 1 & 0.5 & 1000 million or more & 17 & $5001-10000$ & 23 \\
\hline Education & 8 & 3.6 & No response & 69 & $\leq 10001$ & 25 \\
\hline Electricity, gas or water & 4 & 1.8 & & & No response & 21 \\
\hline $\begin{array}{l}\text { Finance and/or } \\
\text { insurance }\end{array}$ & 12 & 5.4 & & & & \\
\hline $\begin{array}{l}\text { Health and community } \\
\text { services }\end{array}$ & 12 & 5.4 & & & & \\
\hline Mining & 11 & 4.9 & & & & \\
\hline Manufacturing & 37 & 17.0 & & & & \\
\hline $\begin{array}{l}\text { Personal and other } \\
\text { services }\end{array}$ & 25 & 11.2 & & & & \\
\hline $\begin{array}{l}\text { Property and business } \\
\text { services }\end{array}$ & 12 & 5.4 & & & & \\
\hline Retail trade & 22 & 9.9 & & & & \\
\hline Transport and storage & 16 & 7.2 & & & & \\
\hline Wholesale trade & 5 & 2.2 & & & & \\
\hline Other & 27 & 12.1 & & & & \\
\hline TOTAL & 222 & 100 & Total & 222 & Total & 222 \\
\hline
\end{tabular}

Table 2 indicates that the majority of respondents (17\%) were from the manufacturing sector in South Africa, followed by personal and other services (11.2\%); retail trade (9.9\%); transport and storage (7.2\%); and communication services (6.3\%). The sector response to this study is in line with the contribution made by each of these major sector groups to the gross domestic product (GDP) of South Africa in 2013. SAInfo (2013) reported that manufacturing, personal and other services, the retail trade, transport and storage, and communication services contributed $12.3 \%, 5.9 \%, 16.2 \%, 9 \%$ and $9 \%$, respectively, to the GDP of South Africa in that year. In fact, according to Media Club South Africa (2013), 
the five sectors that made the largest contribution to South Africa's GDP over the past decade were also the largest respondents in this study.

The majority of the companies participating in the study (96\%) had a total of 201 or more employees in their service. This situation reflects the relative corporate size of the companies that responded, as in South Africa a business with an employee size of larger than 200 is classified as large (National Credit Regulator, 2011:25).

Finally, of the 153 companies that indicated their turnover, 65 had turnovers of less than US $\$ 25$ million; 45 had turnovers of between US $\$ 25$ million and just less than US\$100 million; and 43 had turnovers of US\$100 million and above, with 17 of these turning over US\$1 billion and above. The high annual turnover (above US\$25 million) of the majority of companies in the study indicates that they are large and corporate in nature. This is important, as the study was designed to reflect the current status of ethical behaviour within a corporate environment.

Table 3 shows the items used and the univariate analysis of items for the Code Effectiveness-construct. The univariate statistics indicate a satisfactory consistency across items.

Table 3: Univariate descriptives

\begin{tabular}{|c|c|c|c|c|}
\hline \multicolumn{2}{|r|}{ Code has a positive effect on ... } & \multicolumn{3}{|c|}{ Univariate statistics } \\
\hline Dimension & Item & Count & Mean & $\begin{array}{l}\text { Standard } \\
\text { deviation }\end{array}$ \\
\hline \multirow{5}{*}{ Altruistic } & a) ... earning respect of stakeholders. & 220 & 4.63 & 0.610 \\
\hline & b) ... that it is integral to company philosophy. & 222 & 4.55 & 0.689 \\
\hline & c) ... being a good corporate citizen. & 222 & 4.50 & 0.691 \\
\hline & d) ... enhancing staff morale. & 222 & 4.54 & 0.703 \\
\hline & e) ... increasing staff confidence. & 222 & 4.59 & 0.671 \\
\hline \multirow{6}{*}{ Mercenary } & f) ... improving business performance. & 222 & 4.61 & 0.626 \\
\hline & g) ... enhancing company reputation. & 222 & 4.57 & 0.632 \\
\hline & h) $\quad .$. promoting long-term interests. & 222 & 4.56 & 0.647 \\
\hline & i) $\quad .$. assisting profit. & 222 & 4.50 & 0.710 \\
\hline & j) $\quad$... improving competitive differentiation. & 222 & 4.49 & 0.704 \\
\hline & k) ... increasing customer loyalty. & 222 & 4.47 & 0.716 \\
\hline \multirow{4}{*}{ Regulatory } & I) $\quad .$. avoiding potential problems. & 222 & 4.60 & 0.670 \\
\hline & m) ... focusing employee efforts. & 222 & 4.54 & 0.649 \\
\hline & n) $\quad$... avoiding litigation (i.e. lawsuits). & 222 & 4.57 & 0.654 \\
\hline & o) ... avoiding fines. & 222 & 4.61 & 0.641 \\
\hline
\end{tabular}

Companies were questioned about the effect of their code of ethics on their overall business practices (refer to Table 3). The researchers were interested in whether any patterns would emerge. In general, it would appear that companies in South Africa do view their code of ethics as having a positive effect on their business operations. This positive effect is spread across the three broad dimensions of a code of ethics, namely altruistic, mercenary and regulatory. 
In terms of the altruistic dimension, the statement "Our Code has a positive effect on the earnings of our stakeholders" received the highest score, with a mean value of 4.63, while the statement "Our Code has a positive effect on being a good corporate citizen" received the lowest rating, with a mean score of 4.50. Table 3 shows that the five statements in this dimension received mean scores ranging between 4.50 and 4.63 out of a maximum of 5 , suggesting that South African companies put strong emphasis on developing employees to have a positive attitude towards ethical business practices and conducting their business in a manner that is in line with the ethical business philosophy of the company, so as to bolster their corporate image and strengthen stakeholder relationships.

When considering the mercenary dimension, the statement "Our Code has a positive effect on improving business performance" obtained the highest score, with a mean value of 4.61. The statement "Our Code has a positive effect on increasing customer loyalty" received the lowest rating with a mean score of 4.47 . Table 3 shows that all six statements in this dimension received mean scores ranging between 4.47 and 4.61 out of a maximum of 5. This highlights the importance South African companies attach to ethical business practice in terms of enhancing the reputation of the corporate sector amongst the general public and its stakeholders. Ethical business practice establishes a basis for differentiation and instils trust in the company among the target customer base, resulting in enhanced customer loyalty, which in turn boosts profitability and promotes the long-term interests of all concerned, as all stakeholders want to establish a relationship or continue with an existing one.

As far as the regulatory dimension is concerned, Table 3 shows that the statement "Our Code has a positive effect on avoiding fines" received the highest score, with a mean value of 4.61. The statement "Our Code has a positive effect on focussing employee efforts" received the lowest rating, with a mean score of 4.54 . All four statements in this dimension received mean scores ranging between 4.54 and 4.61 out of a maximum of 5. These results show that South African companies apply a code of ethics to empower employees to act with strong ethical intentions. The business practices of corporate South Africa should be based on ethical principles and comply with the country's regulatory environment, so as minimise any legal challenges that may arise as a result of their actions in the marketplace. Finally, it should be noted that ethical business practices are the foundation on which corporate South Africa conducts its business with customers and builds its relationships with stakeholders.

Exploratory factor analysis (Norusis, 1993; Norusis, 1994) was applied to assess the underlying pattern of dimensions and items of the Code Effectiveness-construct (Table 4). The principal component was used for factor extraction. The orthogonal approach of the varimax method was used to rotate the initial factor solution. A factor analysis of the Code Effectiveness-construct was subsequently performed. The factor solution contains three dimensions and eight items of a construct of code effectiveness. Note that a confirmatory factory analysis was not appropriate, as this study explores new ground for theory development. Previous studies used only qualitative data. 
Table 4: Exploratory factor analysis of the Code Effectiveness-construct

\begin{tabular}{|c|c|c|c|c|c|c|}
\hline Dimension & Item & 1 & 2 & 3 & * & ** \\
\hline \multirow{3}{*}{ Regulatory } & n) Avoiding litigation (i.e. lawsuits) & 0.767 & 0.172 & 0.278 & 0.695 & 0.899 \\
\hline & o) Avoiding fines & 0.756 & 0.233 & 0.161 & 0.651 & 0.880 \\
\hline & m) Focusing employee efforts & 0.713 & 0.149 & 0.366 & 0.665 & 0.834 \\
\hline \multirow{3}{*}{ Altruistic } & a) Earning respect of stakeholders & 0.108 & 0.901 & 0.148 & 0.845 & 0.823 \\
\hline & b) Being integral to company philosophy & 0.299 & 0.757 & 0.345 & 0.781 & 0.791 \\
\hline & c) Being a good corporate citizen & 0.552 & 0.607 & 0.112 & 0.686 & 0.840 \\
\hline \multirow{2}{*}{ Mercenary } & f) Improving business performance & 0.257 & 0.223 & 0.833 & 0.810 & 0.812 \\
\hline & g) Enhancing company reputation & 0.283 & 0.186 & 0.808 & 0.768 & 0.879 \\
\hline \multicolumn{7}{|c|}{${ }^{*}$ Communality per item } \\
\hline
\end{tabular}

As shown in Table 4, the outcome of the factor solution of used dimensions and items of the construct was acceptable (Kaiser-Meyer-Olkin (KMO): 0.841 (overall MSA); Bartlett's test: approximate chi-square: 759,158: df 28: sigma: 0.000). Measures of sampling adequacy ranged between 0.61 and 0.75 . Communalities ranged between 0.65 and 0.85. The Cronbach alpha for each factor ranged between 0.74 and 0.80 . Three factors that indicate acceptable convergent, discriminant and nomological validity, as well as acceptable reliability for each dimension, were subsequently identified. It was concluded that the measurement metrics of the construct of code effectiveness assessed in Table 4 provide support for acceptable validity and reliability. If one examines the loadings against these three factors, the results are indicative of the emphasis placed on ethical business conduct in South Africa over the past twenty years. Since the move to a more inclusive South Africa in the 1990s, there has been a marked emphasis on corporate governance, business ethics and the implementation of legislation to reinforce desired business practices.

The regulatory factors that were loaded were: avoiding litigation in the form of lawsuits, avoiding fines, and focussing employee efforts. Legislation has been put in place in South Africa to ensure that companies act in accordance with acceptable business morals, as society expects of them. There was also a need to familiarise employees with relevant legislation so as to ensure their compliance and mitigate the risk of incurring penalties for the business. South Africa's Companies Act No 71 of 2008, which became effective on 1 May 2011, replacing the old 1973 Companies Act, introduced changes to the regulatory and governance requirements of companies and placed additional demands on them. Some of these requirements pertained to the social and ethical obligations of companies. Deloitte.com (2012) reported that, as a result of deliberations during the public hearings conducted on the Companies Bill by the Portfolio Committee on Trade and Industry in 2007, the need for companies that have significant public interest to not only act responsibly, but to also be seen to be doing so, was recognised and acknowledged to be important. It was felt that such companies should account for their decisions and the results of these decisions, especially with regard to public interest. This resulted in amendments to the act that provide authority to the Ministry of Trade and Industry to 
require certain companies to have social and ethics committees. Companies that are currently required to have such committees include state-owned companies, listed public companies, and companies with a public interest score of 500 points and above in any two of the previous five years.

The South African National Consumer Protection Act (CPA) came into effect on 1 April 2011. The aim of the act is "to promote fairness, openness and good business practice between the providers of goods or services and the consumers who use such goods and services" (Western Cape Government, 2013). Both the amended Companies Act and the CPA stipulate minimum requirements to ensure the protection of South African consumers (SAICA, 2013). Their development and passing into law over the last four years have further focused the attention of South African businesses on being cognisant of their actions in the marketplace and their vulnerability to less than expected employee efforts that may see them facing litigation for breaching corporate governance stipulations.

The altruistic factors that were loaded - i.e. earning the respect of stakeholders, exhibiting behaviour that is integral to company philosophy, and being a good corporate citizen will become increasingly prominent in South African business as it strives to become more globally accepted as a role player with sound ethical business practices. Embedded in the first King Report of 1994 was the desire to do business for the intrinsic worth of the organisation and for the betterment of the society that encouraged its existence.

The King II Report emphasised the nature and importance of corporate governance (Van Tonder, 2006:14). It also highlighted the fact that corporate governance can only have an effect if an inclusive stakeholder approach is pursued. The report clearly indicated that companies cannot only focus on matters of economic efficiency, but should focus greater attention on creating a balance between economic efficiency and societal impact. The altruistic imperative was clearly signaled in the King II Report: economic efficiency must be married to a consideration of the societal impact of the actions of an organisation. The IODSA supports this position, stating that "[b]oards should recognise that companies do not act independently from the societies in which they operate. Accordingly, corporate actions must be compatible with societal objectives of social cohesion, individual welfare and equal opportunities for all” (2002:47).

The mercenary factors that were loaded were improving business performance and enhancing company reputation. All companies need to ensure that their reputation is protected and enhanced; if they do, one would expect their business performance to improve. The King III Report inspires companies to consider "the concept of integrated reporting in terms of which they are expected to report on their strategies, corporate governance, risk assessment, financial performance and sustainability dimensions, and to show how these components are connected to one another, so as to enable all relevant role players to assess a company's performance holistically in terms of the organisation's ability to create and sustain value" (Makiwane \& Padia, 2012:422-423). This ability to sustain value will impact heavily on business performance and, in turn, company reputation. 


\section{Management implications}

The South African corporate sector provided clear evidence of the positive effect of having a code of ethics on its business practices. Evidence provided illustrated that all three dimensions of business practices in corporate South Africa (i.e. altruistic, mercenary and regulatory) guide companies to apply ethical business approaches. It therefore appears that the measurement properties of a construct of code effectiveness do provides clear guidelines to South African companies about ethically responsible business practices that consider the interests of a wide range of stakeholders.

The findings of the study have both practical and theoretical implications. One important implication is that the tested measurement properties of a construct of code effectiveness provide an initial understanding of how such a code of ethics influences business operations in corporate South Africa. A code of ethics framework may also serve as a basis for further investigations on the subject. Other items and constructs may be considered and incorporated in testing the code of ethics framework. To the best of the authors' knowledge, the framework proposed in Figure 1 offers, for the first time, empirical indications of the measurement properties of a construct of code effectiveness.

Many companies perceive an ethical approach to leadership as being central to the development and maintenance of an ethical culture among employees. Conversely, unethical management practices have the largest influence on unethical business practices in the corporate sector. It is therefore imperative for company leadership to ensure that the company's ethical culture (i.e. embedding the organisational value system) is not limited to senior management, but is filtered down to employees throughout the company. McDonald and Zepp (1990:12) are of the opinion that the ethical example set by company leadership should at all times be impeccable. They quote Loucks (1987): "Indeed, without a good example from the top, ethical problems are probably inevitable within your company." Company leadership should therefore use every opportunity to communicate the company's position with regard to ethical business practices and value systems and the alignment of individual and corporate ethical beliefs. Importantly, they should lead by example. Such an approach would be compelling evidence - not only to the company management and employees, but also external stakeholders - of the veracity of what is claimed by the company.

South African companies adhere to corporate codes of business ethics to improve on their business performance. It is therefore imperative that they create an environment that is supportive of the ethical education and development of employees. Companies need to understand that their employees are diverse in their beliefs and opinions and, as a result, may not all share the same ethical values. Companies can strengthen their internal regulatory environment with regard to ethical principles through ongoing staff education. In particular, they should ensure a stronger focus on ethical awareness and ethics training programmes that are in line with the company philosophy and which foster an appreciation for the individual differences of people. They should also recruit potential employees who reflect the ethical values promulgated by the company. 
A company can also enhance awareness of business ethics by distributing current articles on ethical business practice to employees, and presenting visual material such as DVDs on the topic of business ethics to staff. In addition to this, McDonald and Zepp (1990:13) suggest that companies "introduce a counsellor to discuss with employees previous decisions about which they have felt uncomfortable and to explore the reasons for this discomfiture; and in multinationals, discussions can be run on the cultural variations of business ethics, and their effects on decision making, e.g. different cultures view bribery with varying degrees of approval or disapproval, and employees should be made aware of these differences".

If South African managers want to promote ethical business behaviour, they must continuously evaluate how they reward employees and what they reward them for. Somers (2001:186) agrees with McDonald and Zepp (1990:13) when they argue that instead of providing "employees with an opportunity to fiddle their expenses, using the customary system of expense claim forms, some companies are allocating a fixed amount to their employees to cover expenses. The individual is then free to decide how he/she will spend the sum - 'fiddling' is no longer possible. By changing the system, the company has removed the ethical responsibility from its employees' shoulders".

\section{Conclusions and suggestions for further research}

It would seem that companies in South Africa consider the three domains of benefit - altruistic, mercenary and regulatory - as major factors in their profit generation. The question that remains to be asked is: Are companies in South Africa mostly motivated to be ethical through the mercenary consideration of profit maximisation; the altruistic consideration; or the regulatory consideration? Svensson et al. (2006) ask similar questions: Is being ethical seen by companies as a tool to gain competitive advantage in the market place? Is the adage 'good ethics is good business' becoming recognised as a truism by many companies? Do corporations simply view enhanced profit as a positive flow-on effect of ethical business practices, not viewing this as taking a mercenary perspective, but rather an inevitable and realistic one? If the latter is true, what are the motivations behind companies' pursuing this objective? Such research fell outside the scope of this study, but an investigation of this issue would bring deeper insight into the motivations behind South African companies' perceptions of the value to their company of having a code of ethics.

This study provides an empirical foundation for a general Code Effectiveness-construct that consists of specific items for each dimension. It may be used by both researchers and practitioners to assess code effectiveness across contexts and over time. This study is also unusual in that it addressed altruistic, mercenary and regulatory aspects of codes of ethics simultaneously, which is seldom seen and has not been tested in previous studies. Furthermore, the empirical findings of this study about corporate perceptions provide valuable opportunities for further research into how the dimensions of the Code Effectiveness-construct are intertwined and interconnected. In sum, the current study 
makes an essential and relevant contribution to previous studies and existing theory in terms of further developing the general measurement properties of a Code Effectivenessconstruct.

\section{References}

Bisschoff, C. \& Fullerton, S. 2011. Managerial business ethics in South Africa: An exploratory comparison 1987 and 2009. African Journal of Business Ethics, 5:14-25.

BUSA (Business Unity South Africa). 2009. South African Charter of Ethical Business Practice, August. http://www.nacf.org.za/busa_workshop/BUSA_Charter_of_Ethical_Business_Practice.pdf [Accessed: 4 April 2015].

Business Ethics Dictionary. 2016. Code of Ethics. http://www.businessdictionary.com/definition/code-ofethics.html [Accessed: 6 June 2016].

Campbell, D., Moore, G. \& Metzger, M. 2002. Corporate Philanthropy in the U.K. 1985-2000: Some Empirical Findings. Journal of Business Ethics, 39:29-41. DOI: 10.1023/A:1016371731732

Cant, M.C. \& Van Niekerk, C. 2013. Survival or ethically correct? Small business owner's attitude towards ethical concern. 3rd Annual International Conference on Enterprise Marketing and Globalization. Singapore.

Constantinescu, M. \& Kaptein, M. 2015. Mutually Enhancing Responsibility: A Theoretical Exploration of the Interaction Mechanisms between Individual and Corporate Moral Responsibility. Journal of Business Ethics, 129:325-339. DOI: 10.1007/s10551-014-2161-4

Dekker, C. 2002. King III Report. http://www.mervynking.co.za/downloads/CD_King2.pdf [Accessed: 15 January 2015].

Del Fabro, D. 2012. South Africa in need of higher business ethic standing. http://www.skillsportal.co.za/ page/features/corporate-governance-ethics/1425954-South-Africa-in-need-of-higher-business-ethicstanding [Accessed: 10 June 2014].

Delloite.com. 2012. Social and Ethics Committee Resource Guide. http://www2.deloitte.com/content/dam/ Deloitte/za/Documents/governance-risk-compliance/ZA_SocialAndEthics... [Accessed: 19 July 2014].

Fin24tech. 2015. MTN's mega Nigerian fine is “spot on”. http://www.fin24.com/Tech/Opinion/MTNs-megaNigerian-fine-is-spot-on-20151104 [Accessed: 21 December 2015].

Goldman, G., Bounds, M., Buła, P. \& Fudalinski, F. 2012. On the ethical conduct of business organisations: A comparison between South African and Polish business management students. African Journal of Business Ethics, 6(1):75-87. DOI: 10.4103/1817-7417.104705

Groenewald, L. \& Geerts, S. 2013. The South African Business Survey 2013. Ethics Institute of South Africa, Hatfield: Pretoria.

IODSA (Institute of Directors Southern Africa). 1994. King Report on corporate governance in South Africa. http://www.iodsa.co.za/?kinglll [Accessed: 1 March 2015].

IODSA. 2002. Business Ethics codes. http://www.ecgi.org/codes/documents/executive_summary.pdf [Accessed: 12 October 2014].

IODSA. 2009. King code of governance for South Africa. http://www.ecgi.org/codes/documents/executive_ summary.pdf [Accessed: 12 February 2015].

Irwin, J. 2011. Doing business in South Africa: An overview of ethical aspects. London: Institute of Business Ethics.

Kaptein, M. 2008. Developing a Measure of Unethical Behaviour in the Workplace: A Stakeholder Perspective. Journal of Management, 34(5):978-1008. DOI: 10.1177/0149206308318614

Kaptein, M. 2011. Toward Effective Codes: Testing the Relationship with Unethical Behaviour. Journal of Business Ethics, 99:233-251. DOI: 10.1007/s10551-010-0652-5 
Lea, D. 1999. Corporate and public responsibility, stakeholder theory and the developing world. Business Ethics: A European Review 8(3), 151-162. DOI: 10.1111/1467-8608.00143

Loucks, V. 1987. A CEO looks at Ethics. Business Horizons, March/April: 2-6. DOI: 10.1016/0007-6813(87)90001-2

Loyd, H.R., Mey, M.R. \& Ramalingum, K. 2014. Ethical business practices in the Eastern Cape automotive industry. South African Journal of Economic and Management Sciences (SAJEMS), 17(5):569-583.

Maclagan, P. 1992. Management development and business ethics: A view from the UK. Journal of Business Ethics, 11:321-328. DOI: 10.1007/BF00872175

Makiwane, T.S. \& Padia, N. 2012. Evaluation of corporate integrated reporting in South Africa post King III release South Africa - An exploratory enquiry. Journal of Economic and Financial Sciences, 6(2):421-438.

McDonald, G.M. \& Zepp, R.A. 1990. What should be done? A practical approach to business ethics. Management Decision, 28(1):9-14. DOI: 10.1108/00251749010002775

Media Club South Africa. 2013. South Africa's economy: key sectors. http://www.mediaclubsouthafrica.com/ economy/37-economy/economy_bg/111-sa-economy-key-sectors [Accessed: 31 May 2014].

Mirzayev, E. 2015. How Corruption Affects Emerging Economies? http://www.investopedia.com/articles/ investing/012215/how-corruption-affects-emerging-economies.asp [Accessed: 21 December 2015].

National Credit Regulator. 2011. Literature review on small and medium enterprises' access to credit and support in South Africa. http://www.ncr.org.za/pdfs/Research_Reports/Literature\%20Review\%20on\%20 SME\%2\%20to\%20Credit\%20in\%20South\%20Africa_Final\%20Report_NCR_Dec\%202011.pdf [Accessed: 31 September 2014].

Norusis, M.J. 1993. SPSS for Windows: Base System User's Guide Release 6.0. Chicago, IL: SPSS Inc.

Norusis, M.J. 1994. SPSS Professional Statistics 6.1. Chicago, IL: SPSS Inc.

Price, G. \& Van der Walt, A.J. 2013. Changes in attitudes towards business ethics held by former South African business management students. Journal of Business Ethics, 113(3):429-440. DOI: 10.1007/s10551012-1314-6

PWC. 2016. Corporate Governance - King III report - Introduction and overview. http://www.pwc.co.za/en/ king3.html [Accessed: 5 June 2016].

Rondinelli, D.A 2003. Transnational corporations: international citizens or new sovereigns? Business Strategy Review, 14(4):13-21. DOI: 10.1111/j..2003.00281.x

Rossouw, D. 2012. The social and ethics committee handbook. Pretoria: Ethics Institute of South Africa.

SAICA (South African Institute of Chartered Accountants). 2013. The Consumer Protection Act. https://www. saica.co.za/Technical/LegalandGovernance/Legislation/ConsumerProtectionActNo68of2008/tabid/1911/ language/en-ZA/Default.aspx [Accessed: 3 February 2015].

SAICA. 2014. Ethical governance. https://www.saica.co.za/Technical/LegalandGovernance/King/tabid/2938/ language/en-ZA/Default.aspx [Accessed: 15 September 2014].

SAInfo. 2013. South Africa: Economic Overview. http://www.southafrica.info/business/economy/econoverview. htm [Accessed: 30 September 2014].

Schoeman, C. 2012. Business ethics - Is there really such a thing? Professional Accountant. http://www. ethicsmonitor.co.za/Articles/business-ethics.pdf [Accessed: 21 July 2016].

Seegers, G. 2009. King III homes in on share-based remuneration. TaxTalk, September/October.

Sims, R.R. 1992. The Challenge of Ethical Behaviour in Companies. Journal of Business Ethics, 11(7):505-513. DOI: $10.1007 / \mathrm{BF} 00881442$

Somers, M.J. 2001. Ethical Codes of Conduct and Company Context: A Study of the Relationship Between Codes of Conduct, Employee Behaviour and Company Values. Journal of Business Ethics, 30(2):185-195. DOI: 10.1023/A:1006457810654

Svensson, G. \& Wood, G. 2008. Model of Business Ethics. Journal of Business Ethics, 77(3):303-322. DOI: $10.1007 / \mathrm{s} 10551-007-9351-2$ 
Svensson, G., Wood, G. \& Callaghan, M. 2004a. A Comparison between Corporate and Public Sector Business Ethics in Sweden: Similarities and Differences. Business Ethics: A European Review, 13(2/3):166-185. DOI: 10.1111/j.1467-8608.2004.00361.x

Svensson, G., Wood, G. \& Callaghan, M. 2004b. The Commitment of Public Sector in Sweden to Codes of Ethics. International Journal of Public Sector Management, 17(4):302-331. DOI: 10.1108/09513550410539802

Svensson, G., Wood, G. \& Callaghan, M. 2006. Codes of ethics in corporate Sweden. Corporate Governance, 6(5):547-566. DOI: 10.1108/14720700610706054

TopCo. 2014. Top 500 South Africa's best managed companies. http://topco.co.za/publications/top500-southafricas-best-managed-companies) [Accessed: 30 March 2014].

Ukwanada. 2015. The business of business should be ethics, not business. https://www.psychologyafrica. com/2015/01/the-business-of-business-should-be-ethics/ [Accessed: 21 December 2015].

Van Tonder, C.L. 2006. Towards a minimum conceptualisation of ethical company change: The platform provided by the "King II Report". SA Journal of Human Resource Management, 4(3):12-21. DOI: 10.4102/ sajhrm.v4i3.97

Van Zyl, E. \& Lazenby, K. 2012. The role of leadership in reducing unethical behaviour and white-collar crime in a company context. Acta Criminologica, 25(1):58-68.

Western Cape Government. 2013. National Consumer Protection Act. http://www.westerncape.gov.za/ general-publication/national-consumer-protection-act [Accessed: 3 May 2014].

Wood, G. 2002. A Partnership Model of Corporate Ethics. Journal of Business Ethics, 40:61-73. DOI: 10.1023/A:1019990724275

Zona, F., Minoja, M. \& Coda, V. 2013. Antecedents of corporate scandals: CEOs' personal traits, stakeholders' cohesion, managerial fraud and imbalanced corporate strategy. Journal of Business Ethics, 113:265-283. DOI: $10.1007 / \mathrm{s} 10551-012-1294-6$ 